\title{
Zooplankton cultivation and prawn seed-production in an artificial ecosystem
}

\author{
H. Hirat'A \\ Faculty of Fisheries, Kagoshima University; Kagoshima, Japan
}

\begin{abstract}
The cultivation experiments were conducted in two parts: (1) zooplankton cultivation in a heterogeneous system as fundamental research (Experiment I); (2) prawn seed-production in a homogeneous system as applied research (Experiment II). In E x p e r ime n $\mathrm{I}$, several types of apparatus were designed in order to study a feedback system for cultivation of zooplankton (Brachionus plicatilis and Tigriopus japonicus). A 550-1 round transparent tank was used for reserve culture, A 150-1 zigzag stream unit was made of vinyl plates, and connected with the reserve culture tank. In both cases, the water was re-circulated 20 times a day by an airlift pump. A tower-decomposer tank and two blowing cultivators were specially designed for promoting energy-flow. During a 140-day experiment, total wet weight of feed and harvest were $4817 \mathrm{~g}$ of yeast and $4308 \mathrm{~g}$ of zooplankton, respectively. The rate of food conversion was $89.4 \%$ in terms of wet weight and $33.6 \%$ in dry weight. In Experiment II, a $2500 \mathrm{~m}^{3}$-hatchery tank with movable aerators and airlift circulation systems was constructed to maintain an artificial ecosystem for rearing of the prawn Penaeus japonicus. Feeding rate in the $2500 \mathrm{~m}^{3}$-tank was $10.8 \%$ lower than that in the $200 \mathrm{~m}^{3}$-tank, but growth rate in the former was $10.6 \%$ higher than in the latter.
\end{abstract}

\section{INTRODUCTION}

Water pollution due to commercial fish cultivation has recently become a serious problem in south-western Japan. In the Seto Inland Sea, the standing crop of macroalgae has decreased $20 \%$ during the last 20 years. Likewise, the ecosystem has been deformed by industrial waste affluents and abundant biodeposition of fish excretion and excess food.

A similar conditions was noted when culturing aquatic animals in a tank. Faeces of the animals and residues of their diet sink down and accumulate on the bottom of the tank. Such biodeposits, when decomposed, may cause disturbances of the normal energy flow in the water. If algae are cultured in the same tank, they utilize the decomposed materials and thus keep the culture water in a homeostatic state.

In 1964, Hirata tested a system of triple player for seed production in puffer fish. The excess nutrients due to faeces and remaining residue were removed by algae which were illuminated by fluorescent lamps in an artificial stream (see also Kinne, 1976). The copepods fed on the micro-algae but they were, in turn, consumed by 
the fish larvae. However, the stream was too small, and homeostasis of the ecosystem was not maintained for a long period.

In this paper, it is suggested that the culture system of aquatic animals should preferably be maintained as a balanced ecosystem consisting, as in nature, of producers, consumers, and decomposers. The experiments were conducted in two parts: (1) zooplankton culture in a heterogeneous system as a fundamental research project, and (2) prawn seed-production in a homogeneous system as an applied research project.

\section{MATERIALS AND METHODS}

\section{Producers, consumers and decomposers}

Enteromorpha intestinalis, Chatoceros rigidus, Chlorella saccharophila var. saccharopbila and Nitzschia spp. were cultured in the producer tanks prepared in Experiment I. Brachionus plicatilis, Tigriopus japonicus and Penaeus japonicus were

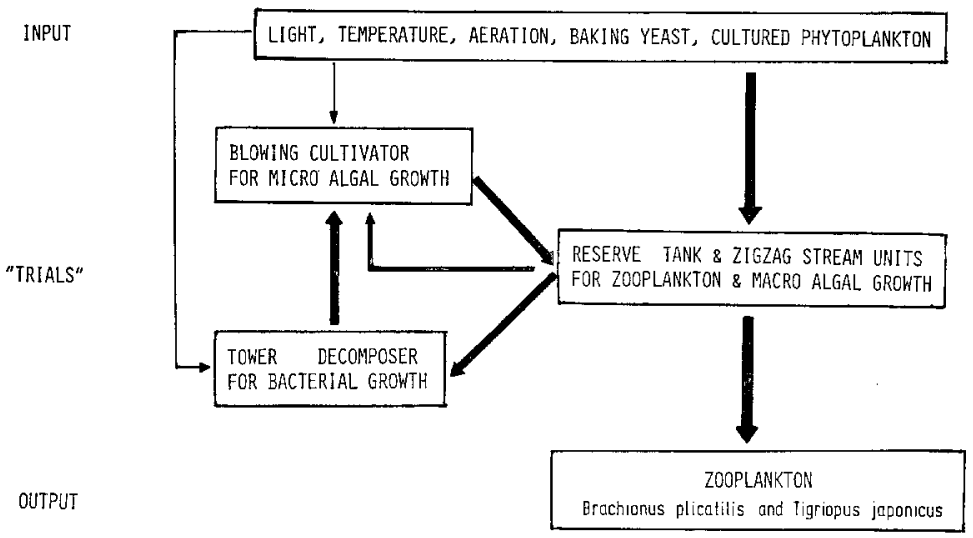

Fig. 1: Flow chart of homeostasis in zooplankton-culture ecosystem

grown as consumers in Experiments I and II, respectively. Several types of bacterial organisms were grown naturally in the waters and served as decomposers in all the experiments. Quantitative analysis of bacterial types was only done in Experiment I.

\section{Apparatus forzooplankton cultivation}

A flow chart of the heterogeneous system for zooplankton culture in Experiment $I$ is presented in Figure 1 . White beam fluorescent lamps (40 w x 8) were switched on for $15 \mathrm{~h}$ during day time and switched off $9 \mathrm{~h}$ at night from 20.30 to 5.30 (Hirata, $1975 \mathrm{a}$ ). Air (about $2.51 \mathrm{~min}^{-1}$ ) was supplied continuously for an airlift pump; $30 \mathrm{~g}$ of baking yeast and 1 or $2 \mathrm{~g}$ of cultured diatoms were fed to the zooplankton every day, in the morning and evening. 
Two 5001 transparent plastic tanks were employed for zooplankton culture; Tank $a$ was employed for the closed recirculation system, Tank $b$ served as the reserve tank. The water was recirculated in each tank by an air-lift pump as illustrated in Figure 2. Polyethylene nets ( 80 meshes) were set on the surface of the stream (Tank a) in order to accelerate the growth of Enteromorpha intestinalis. The average rate of water circulation was about 20 times day-1. The current speed in the stream was about $1.3 \mathrm{~m} \mathrm{~min}^{-1}$. E. intestinalis were harvested from the algae nets after attaining critical density.

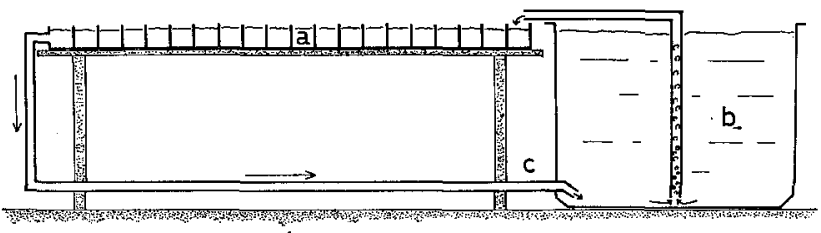

A

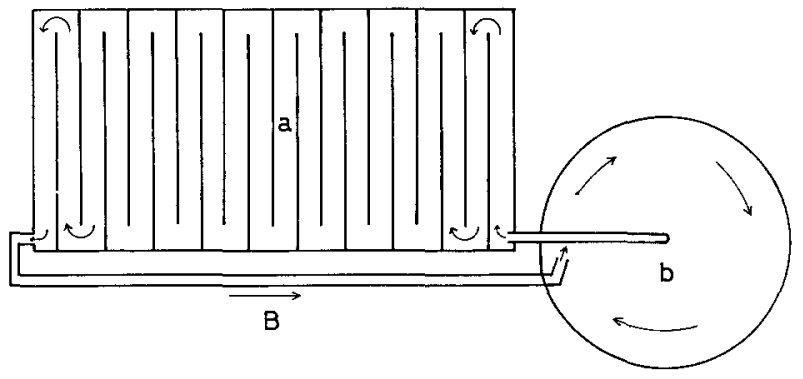

Fig. 2

Fig. 3

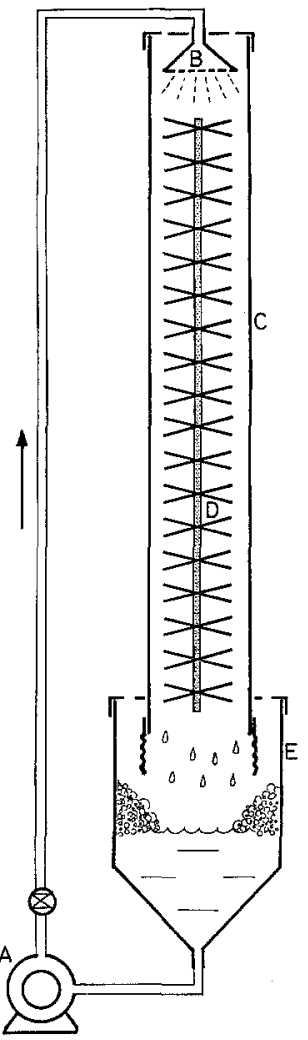

Fig. 2: Schematic diagram of main tank and zigzag stream for cultivation of zooplankton (Tigriopus E Brachionus) and macro alga (Enteromorpha). A side view; B top view; a 1501 zigzag stream unit; b 5501 main cultivation tank; c recirculation pipe

Fig. 3: Schematic diagram of tower decomposer. A circulation pump; B shower nozzle; $C$ vinyl tower; D polyethylene brush; $\mathrm{E}$ reservoir

The faeces and diet residue deposited on the bottom of the stream were removed by a siphon and transferred into a tower decomposer tank which contained a PVC honeycomb settler as shown in Figure 3. The decomposing method used was a modification of the technique reported by Fujiwara et al. (1976). In this method, organic matters, such as faeces, was transformed into inorganic nutrients within 24 h by 2 or 3 bacteria species. 
A blowing cultivator (Fig. 4) was used for the cultivation of micro algae which thrived on the excess nutrients in the zooplankton culture tank. Two 60-1 tanks made of transparent plastic plates were put in a water bath with a thermo-regulator $\left(22.0^{\circ} \pm 2.0 \mathrm{C}^{\circ}\right)$. The medium in the cultivator was aerated and illuminated by white-beam fluorescent lamps $(20 \mathrm{w} \times 16)$ from both sides. About 301 of waste
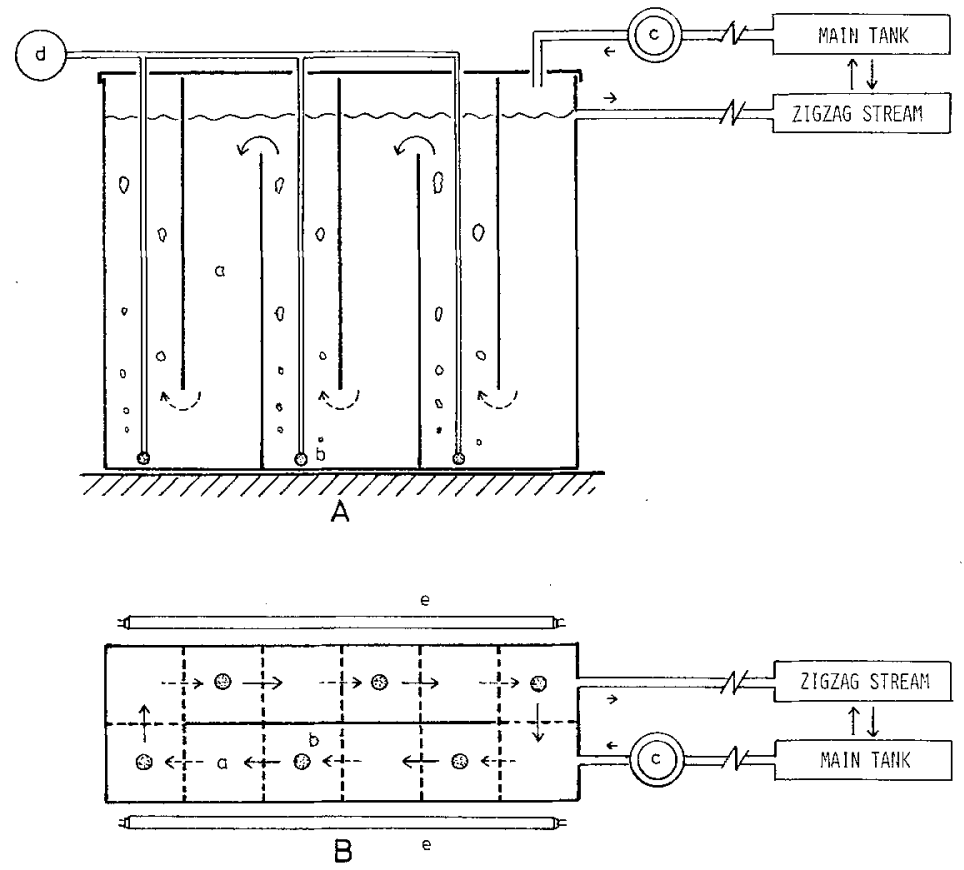

Fig. 4: Schematic diagram of blowing cultivator. A side view; B top view; a blowing cultivator; b air outlet; $c$ recirculation pump; $d$ air entry; e fluorescent lamps

water obtained from the by-products of animal harvesting and 0.51 of excess nutrient from the decomposer tank were pumped into this culture enclosure immediately after the light was turned on every morning (5.30). At the same time, the microalgae cultured in the blowing cultivator were drained into the zigzag stream unit. An automatic time switch and a diaflum pump were used in all processes mentioned above.

\section{Prawn hatchery}

For prawn hatching and rearing, a 2,500 $\mathrm{m}^{3}$ hatchery with attached, movable aerators and an airlift circulator was designed. In order to provide satisfactory aeration, a deep hatching tank was built ( $4 \mathrm{~m}$ depth). Instead of being removed, the biodeposits were recycled by the oxidation processes occurring in the tank. As shown in Figure 5, the moving pipe of the aerator supplied a strong air flow directly 
at the bottom thus preventing the sedimention of particles. Oxidation was ensured by a relatively high dissolved oxygen content of 4 to $7 \mathrm{ppm}$, obtained from an air supply of 0.5 to $1.0 \%$ of the water volume $\mathrm{min}^{-1}$. The culture water in the hatchery was recirculated horizontally by 20 air-lift pipes attached to the inside wall of the tank. The diameter of each air-lift pipe was $20 \mathrm{~cm}$. An example of the daily feeding schedule is presented in Table 1.

\section{Table 1}

Example of daily feeding schedule.

Temperature: $20^{\circ}-25^{\circ} \mathrm{C}$; salinity: $30-35 \%$; $\mathrm{pH}: 7.8-8.4$; dissolved oxygen: $5-7 \mathrm{ppm}$

\begin{tabular}{|c|c|c|c|}
\hline Nauplius & $\begin{array}{l}\text { N1-4 } \\
\text { N5-6 }\end{array}$ & $\begin{array}{l}0-1 \\
1-2\end{array}$ & $\begin{array}{l}\text { No feeding } \\
1 \text { g S. C.* }\end{array}$ \\
\hline Zoea & $\begin{array}{l}\mathrm{Z} 1 \\
\mathrm{Z} 2 \\
\mathrm{Z3}\end{array}$ & $\begin{array}{l}3-4 \\
5-6 \\
7-8\end{array}$ & $\begin{array}{l}1 \mathrm{~g} \mathrm{~S} \text {. C. }+0.1 \mathrm{~g} \text { baking yeast* } \\
1 \mathrm{~g} \mathrm{S.C.}+0.5 \mathrm{~g} \text { baking yeast } \\
1 \text { g S. C. }+500 \text { marine rotifer } * * *\end{array}$ \\
\hline Mysis & $\begin{array}{l}\text { M1 } \\
\text { M2 } \\
\text { M3 }\end{array}$ & $\begin{array}{r}9-10 \\
11-12 \\
13-14\end{array}$ & $\begin{array}{l}1 \text { g. S. C. }+50 \text { brine shrimp:\% } \\
1 \text { g S. C. }+100 \text { brine shrimp } \\
1 \text { g S. C. }+150 \text { brine shrimp }\end{array}$ \\
\hline Postlarvae & $\begin{array}{l}\text { P1 } \\
\text { P2 } \\
\text { P3-5 } \\
\text { P6-10 } \\
\text { P11-20 } \\
\text { P21- }\end{array}$ & $\begin{array}{l}15 \\
16 \\
17-19 \\
20-24 \\
25-34 \\
35-\end{array}$ & $\begin{array}{l}150 \% \text { larval B. W. of neck clam }+100 \text { brine shrimp } \\
150 \% \text { larval B. W. of neck clam }+50 \text { brine shrimp } \\
100 \% \text { larval B. W. of neck clam and frozen shrimp } \\
80 \% \text { larval B. W. of neck clam and frozen shrimp } \\
80 \% \text { larval B. W. of neck clam and frozen shrimp } \\
60 \% \text { larval B. W. of neck clam and frozen shrimp }\end{array}$ \\
\hline \multicolumn{4}{|c|}{$\begin{array}{l}\text { * S. C. (soy cake) and baking yeast per } 10,000 \text { larvae } \\
* \text { Marine rotifer and brine shrimp per larva } \\
+ \text { Neck clam meat minced } \\
+ \text { Weight-ratio of neck clam and frozen shrimp is } 2: 1 .\end{array}$} \\
\hline
\end{tabular}

\section{RESULTS}

\section{Zooplankton culture in a feedbacksystem}

As shown in Table 2, the total wet weight of feed and harvest were $4817 \mathrm{~g}$ of yeast and $4308 \mathrm{~g}$ of zooplankton, respectively. The moisture content, observed at random after the experiment was $69.4 \%$ for baking yeast and $88.5 \%$ for the harvested zooplankton. Therefore, average food conversion was calculated to be $89.4 \%$ in terms of wet weight and $33.4 \%$ in dry weight. The conversion rates increased gradually during cultivation. For example, wet-weight conversion ranged from $49.5 \%$ to $99.7 \%$ during the first half of the experiment, while the rates increased up to $160.6 \%$ between the 91 st and 100 th day.

In general, higher conversion rates were obtained when the Chlorella saccharophila var. saccharophila growth on excess nutrients was intense. The total amount of Chlorella regenerated was $1314 \mathrm{~g}$, and this was estimated to account for $21.4 \%$ of all the food in this cultivation system. 
Growth of Enteromorpha intestinalis also exerted a great influence on the propagation of zooplankton, especially on the survival of Tigriopus japonicus. It was interesting to note the proportion of zooplankton distribution in both zigzag stream tank and round reserve tank. Average densities of Brachionus plicatilis were 80 individuals $\mathrm{ml}^{-1}$ in the stream and 60 individuals $\mathrm{ml}^{-1}$ in the tank. Comparing

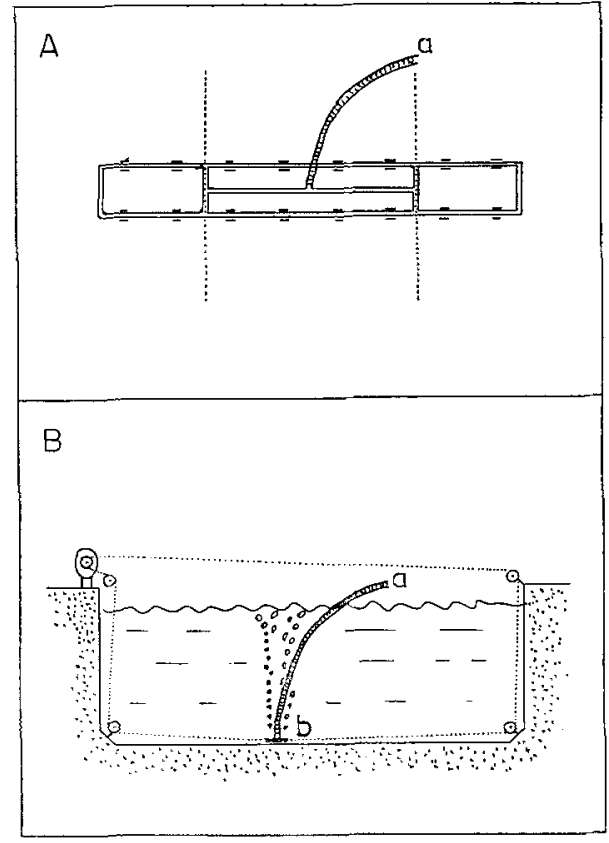

Fig. 5: Schematic views of movable aerator. A top view; B side view; a aeration tube; b air outlet

the population densities between zigzag stream and reserve tank, the $B$. plicatilis abundance was calculated to be $6: 4$, that is about $60 \%$ in the stream and $40 \%$ in the reserve tank. In contrast, the abundance of $T$. japonicus was $9: 1(90 \%$ in the stream and $10 \%$ in the reserve tank). Therefore, there is not much difference in the abundance of $B$. plicatilis in the stream or reserve tank, but the $T$. japonicus abundance in the stream was 9 times higher than in the reserve tank. This tendency was pronounced when $E$. intestinalis grew well near the water surface of the zigzag stream.

Standing crops of zooplankton are presented in Figures 6 and 7. The total body volume of Brachionus plicatilis and Tigriopus japonicus in both stream and reserve tank increased rapidly during the first 30 days of the experiment. Thereafter, the population density of $B$. plicatilis increased gradually from a volume of 189 to $254 \mathrm{ml}$, but became stable during the last 70 days at about $240 \mathrm{ml}$ body volume, because of optimum feeding and harvesting rates. The population density of $T$. japonicus showed little variation over a range of 22 to $57 \mathrm{ml}$ of body volume 


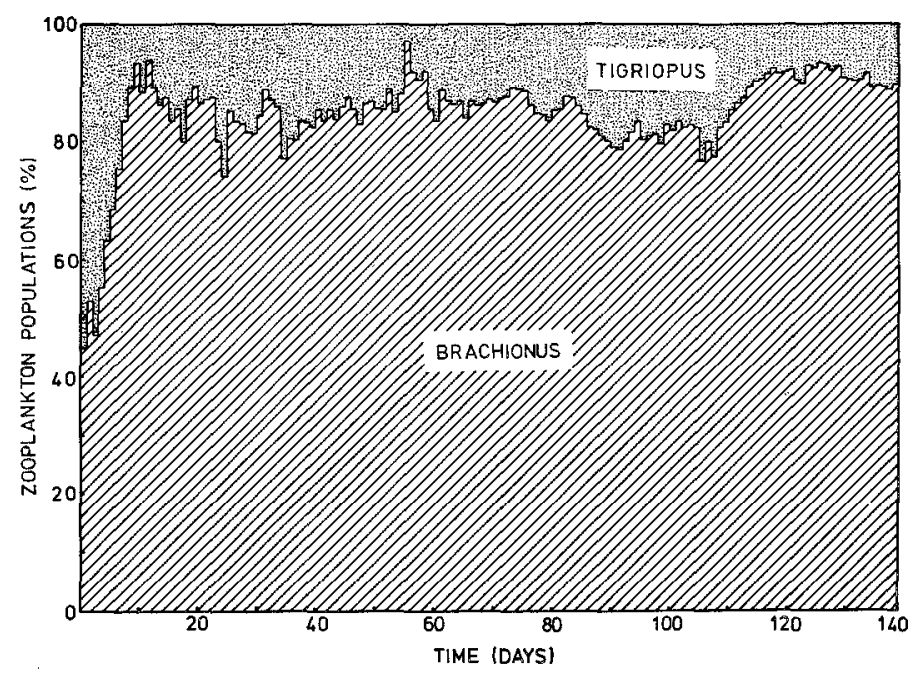

Fig. 6: Homeostasis of Brachionus and Tigriopus populations during experiment

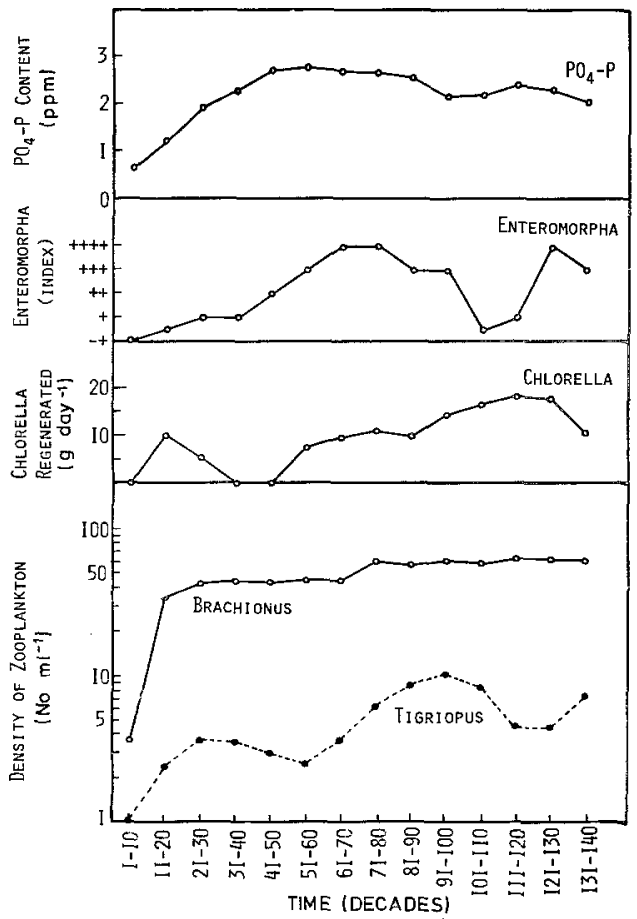

Fig. 7: Homeostatic states of zooplankton, algae and $\mathrm{PO}_{4}-\mathrm{P}$ 
throughout the experiment as shown in Table 3 and Figure 7. It seems that the population densities of $B$. plicatilis and $T$. japonicus were related to the growth of Cblorello saccharophila var. saccharophila and Entheromorpha intestinalis grown in stream and tank, respectively. The population of T. japonicus was affected indirectly by the growth of $E$. intestinalis with a delay of 20 or 30 days.

Inorganic phosphate $\left(\mathrm{PO}_{4}-\mathrm{P}\right)$ contents of the culture water, measured each day (10-day period averages) are shown in Figure 7. The PO4-P value at the beginning of the experiment was $0.62 \mathrm{ppm}$; it increased to $2.77 \mathrm{ppm}$ in the 5 th decade. Then it decreased again gradually to $2.03 \mathrm{ppm}$ in the final decade of the experiment, depending on the growth of Chlorella saccharophila var. saccharopbila and Enteromorpha intestinalis in the waters.

The experiment was initiated with the same body volume at a level of $50 \%$ each, of Brachionus plicatilis and Tigriopus japonicus. However, B. plicatilis became the dominant species about 10 days later. Thereafter, the relative species abundance remained almost constant at about $80 \% \mathrm{~B}$. plicatilis and $20 \% \mathrm{~T}$. japonica.

\section{Prawn rearing experiment}

Results of prawn rearing experiments are summarized in Tables 4 and 5, comparing a $2500-\mathrm{m}^{3}$ hatching tank with a movable aerator to the routine method employed with $200-\mathrm{m}^{3}$ tanks.

The average densities of diatoms such as Chaetoceros rigidus, Nitzschia sp. in the $2500-\mathrm{m}^{3}$ and $200-\mathrm{m}^{3}$ tanks were $89.4 \pm 8.0$ and $73.9 \pm 4.9$ cells $\mathrm{ml}^{-1}$, respectively. The density was calculated to be 100 in $200-\mathrm{m}^{3}$ tank and 212.0 in $2500-\mathrm{m}^{3}$ tank. Therefore on the average, diatom growth in the larger tank was $121 \%$ higher than that in the smaller one.

Artemia salina nauplii were fed to the prawn larvae after these attained the mysis stage. Feeding rates were 215 nauplii larvae ${ }^{-1}$ day $^{-1}$ in the $2500-\mathrm{m}^{3}$ tank. The feeding index of Artemia nauplii in the $200-\mathrm{m}^{3}$ tank was 100.0 ; in the $2500-\mathrm{m}^{3}$ tank, 89.2. Hence, the feeding rate in the large tank was $10.8 \%$ lower than that in the small one.

On the other hand average growth of postlarvae in a $2500-\mathrm{m}^{3}$ hatchery was $9.4 \mathrm{mg}$, and greater than that in $200-\mathrm{m}^{3}$ tanks $(8.5 \mathrm{mg})$. The index difference between large and small tanks were 110.6 to 100.0 .

Survival rates in the larger tank were $85.3 \%$ and $78.9 \%$ in the small tank. However, standard deviations of the mean in the large and small tanks were 13.0 and 28.1, respectively. This means that survival rates in the $200-\mathrm{m}^{3}$ tank fluctuated very much, and that in the large tank it was more stable.

A big difference in postlarval density was found in the two types of tanks. Average densities in the $200-\mathrm{m}^{3}$ tank were $12.5 \times 10^{3} \mathrm{~m}^{-3}$; in the $2500-\mathrm{m}^{3}$ tank $8.8 \mathrm{x}$ $10^{3} \mathrm{~m}^{-3}$ (due to the small number of gravid females provided at the beginning of the rearing experiment). On the average, in all experiments, 0.4 female $\mathrm{m}^{-3}$ were used in the larger tank and 1.0 female $\mathrm{m}^{-3}$ in the small tanks case. 


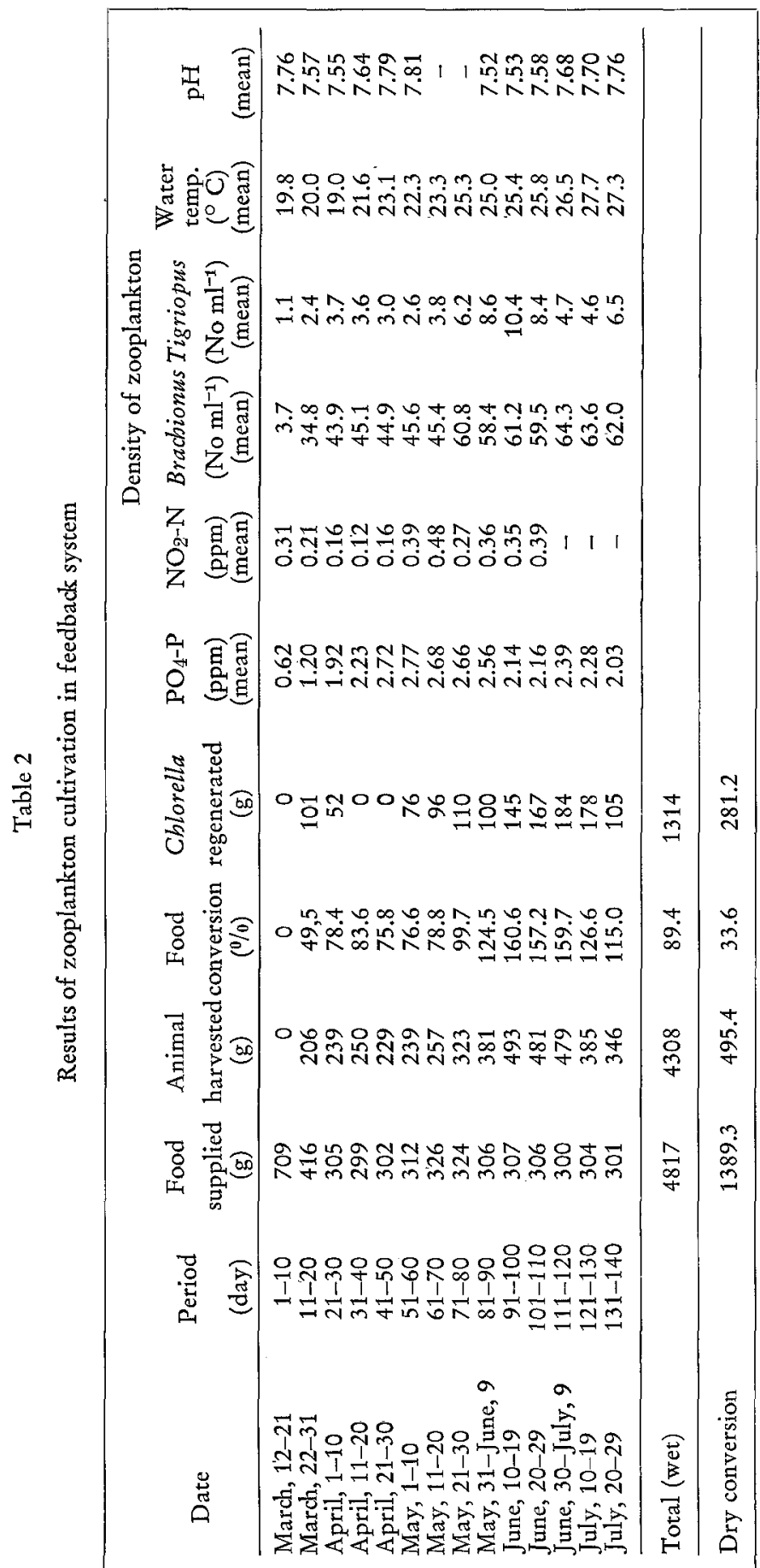




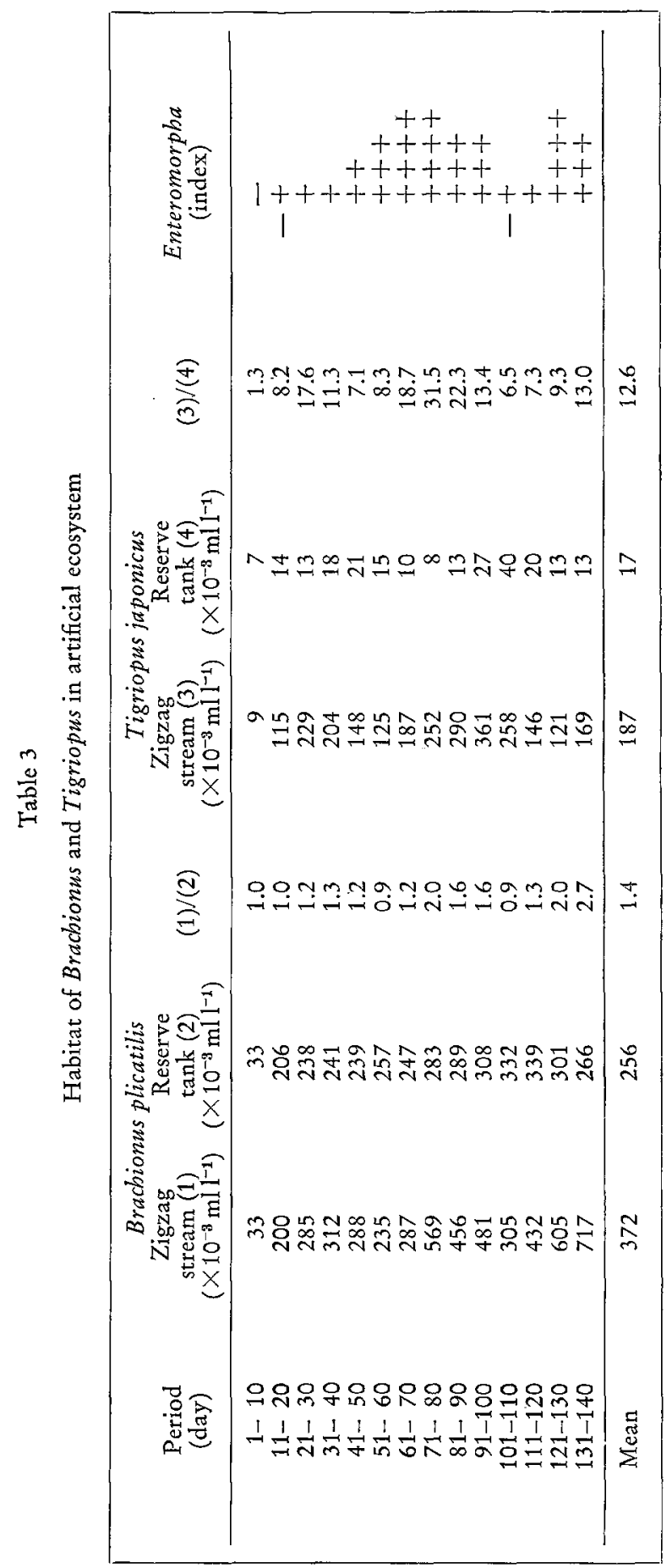




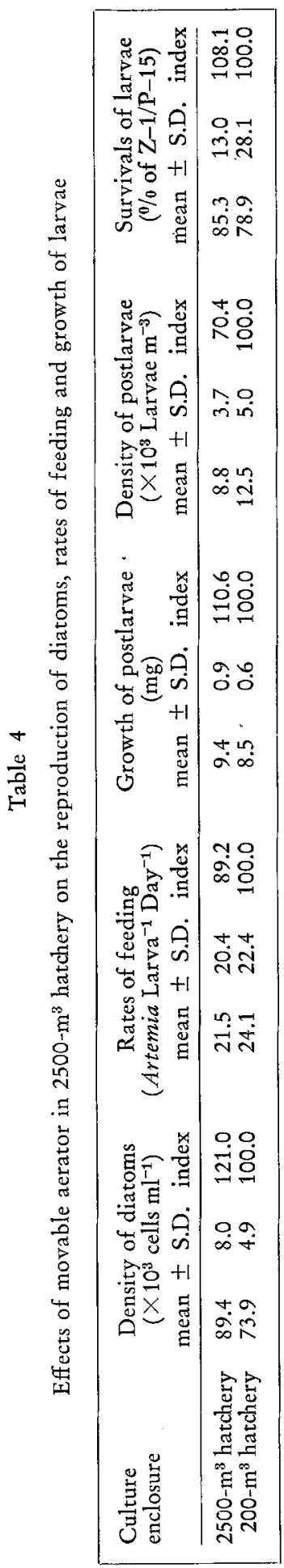


The numbers of postlarvae produced in both types of hatching tanks are presented in Table 5. The total number of seeds ( $\mathrm{P}-15)$ produced in $2500-\mathrm{m}^{3}$ and $200-\mathrm{m}^{3}$ tanks were $66000 \times 10^{3}$ larvae and $7500 \times 10^{3}$ larvae, respectively. Average seedproduction at a given time was $22,000 \times 10^{3}$ larvae in the large and $2500 \times 10^{3}$ larvae in the small tank.

Table 5

Results of prawn seed-production in $2500-\mathrm{m}^{3}$ and $200-\mathrm{m}^{3}$ hatching tanks

\begin{tabular}{|c|c|c|c|c|c|c|c|c|}
\hline $\begin{array}{l}\text { Experi- } \\
\text { ment }\end{array}$ & Period & $\begin{array}{l}\text { Water } \\
\text { tempera- } \\
\text { ture }\left({ }^{\circ} \mathrm{C}\right)\end{array}$ & $\begin{array}{c}2500- \\
\text { No. of } \\
\text { per tank } \\
\text { Z-1 }\end{array}$ & $\begin{array}{l}\mathrm{m}^{3} \text { hatch } \\
\text { larvae } \\
\left(\times 10^{3}\right) \\
\mathrm{P}-15\end{array}$ & $\begin{array}{l}\text { ing tank } \\
\text { survival } \\
\text { rate }(0 / 0)\end{array}$ & $\begin{array}{r}200-r \\
\text { No. of } \\
\text { per tank } \\
Z-1\end{array}$ & $\begin{array}{l}\mathrm{m}^{3} \text { hatchin } \\
\mathrm{f} \text { larvae } \\
\mathrm{k}\left(\times 10^{3}\right) \\
\mathrm{P}-15\end{array}$ & $\begin{array}{l}\text { ng tank } \\
\text { survival } \\
\text { rate }(\%)\end{array}$ \\
\hline Exp. 11-1 & April-June & $20-23$ & 16,000 & 14,000 & 87.5 & 3,340 & 3,000 & 89.8 \\
\hline Exp. 11-2 & June-July & $24-26$ & 33,000 & 32,000 & 97.0 & 3,160 & 3,160 & 100.0 \\
\hline Exp. 11-3 & July-August & $27-29.5$ & 28,000 & 20,000 & 71.4 & 2,850 & 1,340 & 47.0 \\
\hline Mean & & 24.9 & 25,670 & 22,000 & 85.7 & 3,120 & 2,500 & 80.1 \\
\hline
\end{tabular}

Dissolved oxygen concentrations ranged from 7 to $10 \mathrm{ppm}$ in the $2500-\mathrm{m}^{3}$ tank and 3 to $6 \mathrm{ppm}$ in the $200-\mathrm{m}^{3}$ tank. Hence, the oxygen content in the large tank was about twice as high as that in the small tank because of the aeration provided by the movable aerator in the $2500-\mathrm{m}^{3}$ tank. The amount of air supplied equaled about 0.5 to $1.0 \%$ of the water volume $\mathrm{min}^{-1}$. Minimum and maximum water temperatures were $20^{\circ} \mathrm{C}$ and $29.5^{\circ} \mathrm{C}$, respectively, depending on the season (spring to summer). The $\mathrm{pH}$ values varied from 8.0 to 8.4 . There was no significant difference in $\mathrm{pH}$ between the $2500-\mathrm{m}^{3}$ and $200-\mathrm{m}^{3}$ tanks because the culture water was renewed when the $\mathrm{pH}$ decreased below 8.0 .

No sedimentation was found on the bottom of the $2500-\mathrm{m}^{3}$ tank (diving observation). Organic aggregations remained suspended all the time due to the movable aerator, and were oxidized by the strong aeration provided (movable aerator, air-lift). This contrasts with the $200-\mathrm{m}^{3}$ tank where biodepositions accumulated in the corners or on the floor, even during mixing with an agitator (Akazawa, 1973).

\section{DISCUSSION}

In general, the food conversion of Bracbionus plicatilis, fed baking yeast, was estimated to be about 20 to $30 \%$ in terms of wet weight. The corresponding conversion was $89.7 \%$ in wet weight and $33.4 \%$ in dry weight. These values are about 3 times higher than those obtained previously (Hirata \& Mori, 1967; Hirata, 1974). Two possible reasons for this should be considered. The first reason for the high conversion rate obtained might be due to biodeposition feedback. That is, Chlorella saccharophila var. saccharophila developed due to excess nutrients originating from faeces and food remains. The amounts of Chlorella produced and the feed supplied were $1314.0 \mathrm{~g}$ and $4817.0 \mathrm{~g}$, respectively. Therefore, the feedback rate was $21.5 \%$ during the 140-day experiment. The second reason is probably due to water-quality 
homeostasis regulated by the propagation of Enteromorpba intestinalis in the zigzag stream and of C. saccharophila in the blowing cultivator.

Enteromorpha intestinalis also exerted great influence on the development of Tigriopus japonicus nauplii. The density of the $T$. japonicus nauplii increased initially, but decreased again about 30 or 40 days after the E. intestinalis bloom. It may be assumed that $E$. intestinalis acted in three ways: (1) supplying shelter for T. japonicus: (2) using up nutrients and producing oxygen (3) serving as food (zoospores) for $T$. japonicus.

In Experiment II, the diatom density in the $2500-\mathrm{m}^{3}$ hatchery was higher than that in the $200-\mathrm{m}^{3}$ tanks. This may have resulted from the use of the movable aerator for bottom cleaning and oxygen supply (Hirata, $1975 \mathrm{~b}$ ). The aerator prevented sedimentation of organic material on the bottom of the tank, and supplied oxygen to the suspended particles. The growth of diatoms influenced the feeding, growth and survival of the larvae. Lower feeding rates with higher larvae growth were obtained in the $2500-\mathrm{m}^{3}$ tank. Hence, the energy-flow could be promoted by the movable aerator in the $2500-\mathrm{m}^{3}$ hatchery. The experiment was repeated and practically confirmed at the Shibushi Station of the Seto Inland Sea Farming Fisheries Association in 1976.

Acknowledgements. I wish to express my hearty thanks for the kind assistance in conducting Experiment II to all members of the Shibushi Station of Seto Inland Sea Farming Fisheries Association. Experiment I was kindly supported by students of Fish Cultivation Physiology, Faculty of Fisheries, Kagoshima University, Japan.

\section{LITERATURE CITED}

Akazawa, T., 1973. Effects of gearing agitator on the seedproduction of prawn. Farm. Fish. Tech. Develop. Res. 2, 49-55. (In Japan).

Fujiwara, M., et al. 1976. A method of biological purification of waste materials in hospitals and medical laboratories. Environmental purifications by micro-organisms. Rep. Special Res. Grant, Japan, Minstry Educ. 178-179. (In Japan.).

Hirata, H., 1964. Rearing methods of puffer, Sphaeroides rubripes. Yooshoku 1, 34-37. (In Japan.).

- 1974. An attempt to apply an experimental microcosm for the mass culture of marine rotifer, Brachionus plicatilis MULLER. Mem. Fac. Fish. Kagoshima Univ. 23, 163-172.

- 1975 a. Preliminary report on the photoperiodic acclimation for growth of Cblorella cells in synchronized culture. Mem. Fac. Fish., Kagoshima Univ. 24, 1-6.

- $1975 \mathrm{~b}$. An introduction to the rearing methods of prawn, Penaeus japonicus BATE in Japan. Mem. Fac. Fish. Kagoshima Univ. 24, 7-12.

- \& Mori, Y., 1967. Mass-culture of marine rotifer, Brachionus plicatilis, fed the baking yeast. Saibai Gyogyo 5, 36-40. (In Japan.).

Kinne, O., 1976. Cultivation of marine organisms: water quality management and technology. In: Marine ecology. Ed. by O. Kinne. Wiley, London 3 (1), 19-300.

Author's address: H. Hirata

Faculty of Fisheries

Kagoshima University

Kagoshima City

Japan 